\title{
Sponge growth on the Cenomanian carbonate shelves of the Carpathian Basin: a record from spicule-rich turbidites
}

\author{
MARTA BĄK, ZBIGNIEW GÓRNY \& KRZYSZTOF BĄK
}

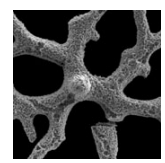

\begin{abstract}
The composition and features of numerous bioclasts found in the sandy/silty fraction of turbidite layers in the Middle-Upper Cenomanian deep-water sediments of the Silesian Nappe in the Outer Carpathians, dominated by sponge spicules, suggest that they originated from the growth and destruction of sponge assemblages formed on shelves of the northern margin of the Silesian Basin. The morphological types of spicules, by comparison with fossil and living species, lead to their attribution predominantly to three orders: Lithistida, Hadromerida and Astrophorida. Sponges lived in association with other benthic fauna such as calcareous benthic foraminifers and echinoids. Many sponge spicules were calcified in their primary environment before their redeposition by turbiditic flows. Favourable conditions for development of sponge assemblages occurred during the Cenomanian transgressions, being related to balanced delivery of sediment particles trapped by sponges and waters enriched with nutrients. The amount of nutrients absorbed by sponges is related to the dissolved silica content that originated from two sources: 1) terrestrial chemical weathering on the low-gradient plains of the shelves and 2) opal grains, such as siliceous plankton, suspended in the water column during bloom periods forced by seasonal upwelling. $\bullet$ Key words: demosponge, spiculite, turbidite, Silesian Basin, Outer Carpathians, Cenomanian.
\end{abstract}

BĄK, M., GÓRnY, Z. \& BĄK, K. 2015. Sponge growth on the Cenomanian carbonate shelves of the Carpathian Basin: a record from spicule-rich turbidites. Bulletin of Geosciences 90(3), 651-666 (8 figures). Czech Geological Survey, Prague. ISSN 1214-1119. Manuscript received November 14, 2014; accepted in revised form July 8, 2015; published online September 8, 2015; issued September 30, 2015.

Marta Bąk(corresponding author) \& Zbigniew Górny, Faculty of Geology, Geophysics and Environmental Protection, AGH University of Science and Technology, Al. Mickiewicza 30, 30-059 Kraków, Poland; martabak@agh.edu.pl, zgorny@agh.edu.pl • Krzysztof Back, Institute of Geography, Pedagogical University of Cracow, Podchoraziych 2, 30-084 Kraków, Poland; sgbak@cyf-kr.edu.pl

The Mesozoic was a period when sponges successively developed, forming widespread marine bioconstruction. The major siliceous sponge radiation and diversification occurred during the Late Jurassic, when sponge-bearing facies became widespread along the northern margin of the Western Tethys (Wiedenmayer 1980). The Cretaceous was another period of relatively diverse sponge fauna growth in the epicontinental seas surrounding the ancient Tethys Ocean. As a record of successive sponge growth, siliceous sponges are very common in the Upper Cretaceous sediments of Europe (e.g., Schrammen 1910-1912, Hurcewicz 1966, Ulbrich 1974, Świerczewska-Gładysz 2006, Olszewska-Nejbert \& Świerczewska-Gładysz 2011), correlated with the peak of the Upper Cretaceous transgression in the Campanian (Pisera 1999), and in marine facies distributions. Demosponges recorded from those times commonly occur in sandy-glauconitic facies (e.g., Reid 1962), marls (e.g., Hurcewicz 1966), opokas (= siliceous chalk or siliceous limestones) (e.g., Defretin-Lefranc 1960, Reid 1962, Świerczewska-Gładysz 2006) and limestones (e.g., Schrammen 1910-1912).

During the Cenomanian, siliceous sponge assemblages were numerous in epicontinental seas along the West European Platform (e.g., Roemer 1864, Hinde 1883, Moret 1926, Reid 1958, Defretin-Lefranc 1960, Trest'jan 1972). However, in this period, lithistid demosponges prevailed over hexactinellids, which were relatively rare (e.g., Termier \& Termier 1980, Olszewska-Nejbert \& Świerczewska-Gładysz 2013).

A consequence of common sponge growth during the Cenomanian was an accumulation of sediments with high admixtures of isolated sponge spicules in the deep basins, where spicules were transported by turbidity currents from shallower parts and admixed to different deep-water deposits. Such processes also played an important role in the Outer Carpathian basins, spreading out along the southern 

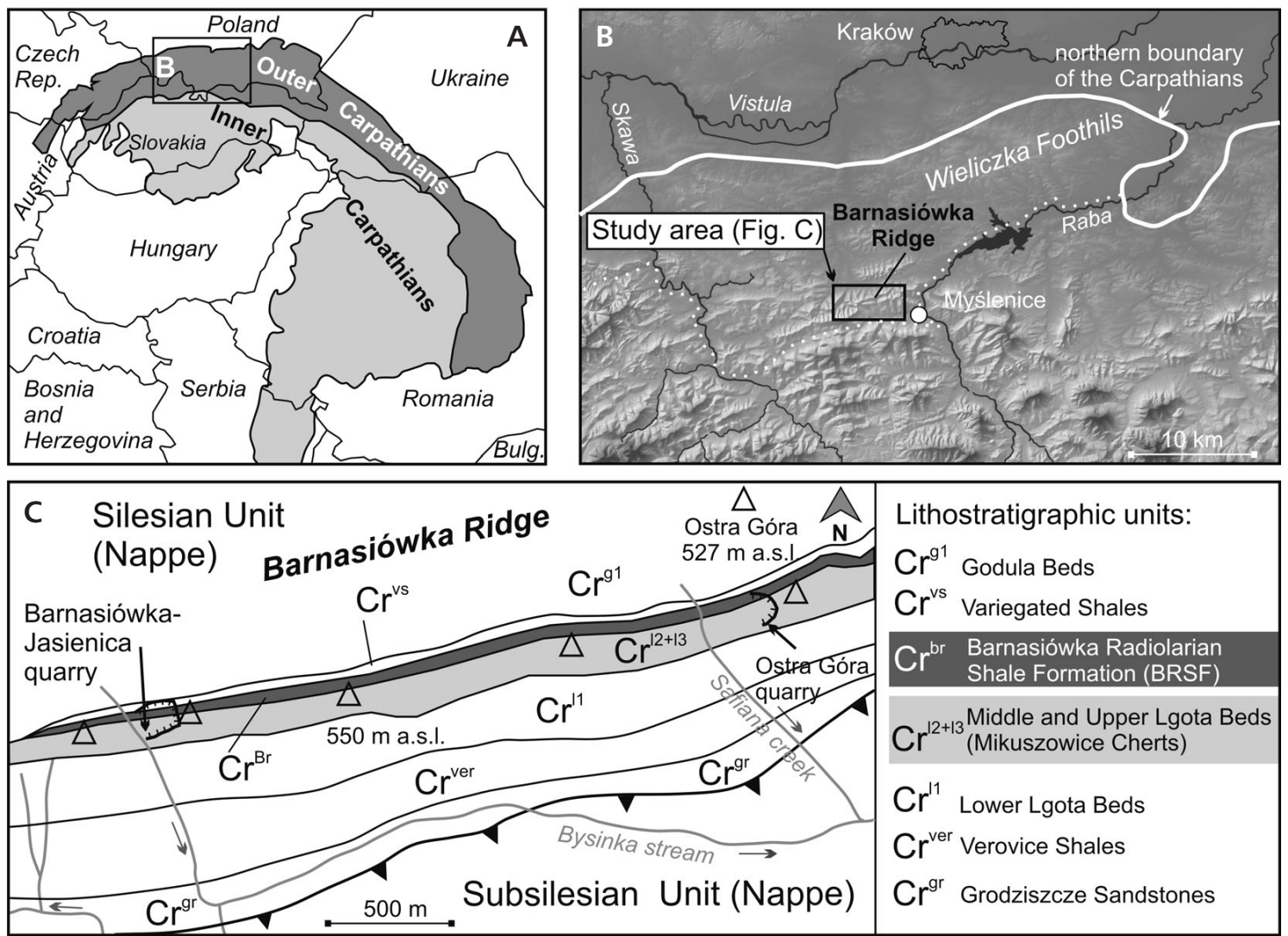

Figure 1. Location of the study area. $\bullet$ A - Outer Carpathians on the background of simplified geological map of Carpathians (pale grey and dark grey colors) and their foreland. $\bullet$ B - location of studied areas in the Western Carpathians with contour map (adapted from Bryndal 2014). $\bullet$ - geological map of study area in the Barnasiówka Ridge (Wieliczka Foothills, Outer Carpathians; map after Burtan 1964, Burtan \& Szymakowska 1964, Bąk et al. 2001).

edge of the West European Platform during Cretaceous times. The Cenomanian, in particular, was a period when turbidite currents carrying spicule-rich sediments flowed

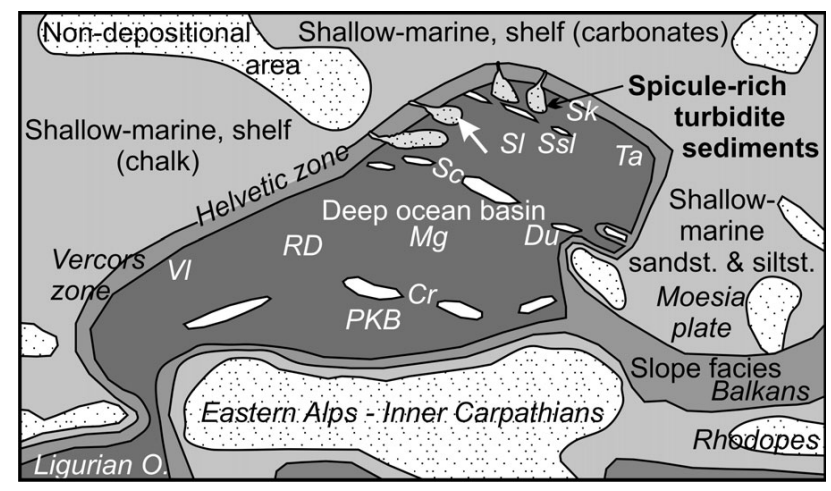

Figure 2. Palaeogeographical map of the Western Tethys during mid-Cretaceous (after Birkenmajer 1986, Golonka et al. 2000; simplified) showing position of spicule-rich turbidite cones along the Carpathian basins and location of the studied sections (white arrow). Abbreviations of names on the map: $\mathrm{Cr}$ - Czorsztyn Ridge, $\mathrm{Du}$ - Dukla Basin, $\mathrm{Mg}-$ Magura Basin, $P K B$ - Pieniny Klippen Belt Basin, $R D$ - Rheno-Danubian Basin, $S c$ - Silesian Ridge (cordillera), $S k$ - Skole Basin, $S l$ - Silesian Basin, $S s l$ - Subsilesian submerdged ridge, $T a$ - Tarcau Basin, $V l$ - Valais Trough. from the Outer Carpathian shelves, forming wide turbidite bodies in the sea floor of the Silesian-Subsilesian and Skole sub-basins. Currently, extensive spicule-rich turbidite bodies occur in the Outer Carpathian nappes in the Czech and Polish Carpathians and continue further east in the Silesian-Chornohora nappe of the Ukrainian Carpathians (e.g., Sujkowski 1933; Książkiewicz 1951, 1956; Unrug 1959; Alexandrowicz 1973). The previous lithostratigraphical, microfacial and palaeontological investigations showed the main features of these sediments and their stratigraphic position (e.g., Bąk K. et al. 2001; Bąk M. 2000, 2004, 2011; Bąk M. et al. 2005, 2011, 2015). These are fine-grained turbidities consisting of detrital material mixed with biogenic particles, which are predominantly siliceous spicules of Demospongiae. Redeposited material is intercalated with deep-water, hemipelagic, non-calcareous clays including only radiolarians and deep-water agglutinated foraminifers among the microfossils. This huge mass of spicule-rich material was derived from an area occupied by a dense population of siliceous sponges, which thrived in a habitat favourable to their growth.

This paper focuses on particularly well-preserved sponge spicules from spicule-rich turbidites in the Silesian 
Nappe of the Outer Carpathians (Fig. 1). Using the new palaeontological data related to sponge spicules from this area, we interpret the features of the source area from which such a mass of biogenic material was delivered to the deep-sea basin floor. We also give some suggestions on the environmental conditions, which supported the development of sponge communities.

\section{Geological setting}

The Outer Carpathians (Fig. 1A, B) comprises several nappes thrust over each other from SSW to NNE, which were folded mainly during the Middle and Late Miocene (e.g., Książkiewicz 1977, Oszczypko 2004). The Silesian Nappe belongs to the outer group of nappes and forms a wide belt along the margin of the Magura Nappe within the Czech, Polish and Ukrainian territories (Książkiewicz 1962).

During the Cretaceous, the present day Outer Carpathian area consisted of several deep longitudinal troughs (Fig. 2) separated by shallows (submarine) or emergent ridges. The sediments of the Silesian Nappe were deposited within the Silesian Basin, restricted to the south by an exotic Silesian ridge and to the north by shelves of a marginal part of the West European Platform and by a submarine Subsilesian ridge reconstructed on the basis of facies and microfossil assemblages (Książkiewicz 1962). The sedimentation in the Silesian Basin began at least by the Late Jurassic (e.g., Książkiewicz 1956, 1977; Koszarski \& Ślączka 1973). During mid-Cretaceous times, an acceleration of turbiditic sedimentation, including spicule-bearing turbidites, occurred in this area. The studied sediments came from the Middle-Late Cenomanian stage, followed by sedimentation of organic-rich claystones across the Cenomanian-Turonian boundary (e.g., Bąk K. et al. 2001).

Lithostratigraphy. - The lithostratigraphy of these sediments has been presented previously by Bąk K. et al. (2001), Bąk M. (2000, 2004, 2011), and Bąk M. et al. (2005, 2011). The spicule-bearing turbidites are distributed among three successive lithostratigraphic units of the Silesian Nappe (Fig. 3): the upper part of the Middle Lgota Beds, Mikuszowice Cherts (equivalent of the Upper Lgota Beds), and the lower part of the Barnasiówka Radiolarian Shale Formation (Bąk M. et al. 2011). The Middle Lgota

Figure 3. Lithostratigraphic subdivision with stratigraphic logs of the Middle-Upper Cenomanian succession in the Barnasiówka-Jasienica and Ostra Góra quarries (Silesian Nappe, Polish Outer Carpathians; adapted from Koszarski \& Ślączka 1973, supplemented by Bąk et al. 2001). Numbers signed on the log correspond to samples with microfossils presented on Figs 4-8. BRSF - Barnasiówka Radiolarian Shale Formation.

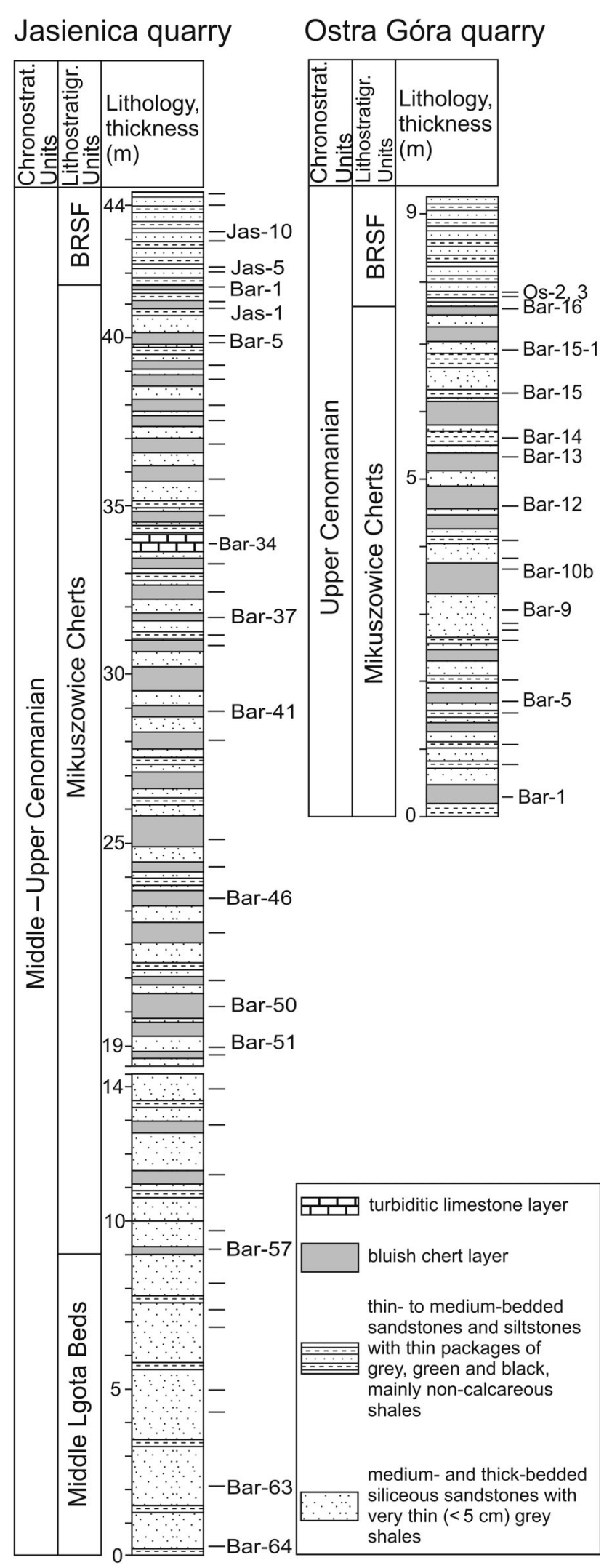


Beds consist mostly of thin- and medium-bedded, siliceous, dark, fine-grained sandstones, which are interbedded with black, grey, green and spotty non-calcareous claystones. The spicule-rich turbidites occur in the upper part of this division. The Mikuszowice Cherts are composed of siliciclastic to calcareous medium- and thick-bedded sandstones with abundant biogenic admixture, which consists mostly of sponge spicules. This unit represents the main body of the spicule-bearing turbidites in the Silesian Nappe. The characteristic feature of this unit is an occurrence of bluish cherts in the middle and upper parts of the beds (Fig. 3). The number of sponge spicules is considerably lower in the thin- to medium-bedded sandstones of the Barnasiówka Radiolarian Shale Formation (BRSF), an overlying lithostratigraphic unit. The spicule-bearing layers disappear within the BRSF near the base of organic-rich claystones, corresponding to the Oceanic Anoxic Event 2 (OAE2; Bąk K. 2007c).

The Mikuszowice Cherts have facies equivalents in other tectonic-facies zones (nappes) of the Outer Carpathians. They are replaced by the Gaize Beds (thin-bedded siliceous sandstones containing numerous sponge spicules) in the Subsilesian Nappe (Alexandrowicz 1973) and by the Siliceous Marls (grey and grey-green calcareous mudstones, partly siliceous, with admixture of sponge spicules) in the Skole Nappe (Bąk K. 2007b).

Stratigraphy and age approach. - The deposition of the spicule-rich turbidites in the Silesian Basin (upper part of the Middle Lgota Beds, Mikuszowice Cherts and the lower part of the BRSF) occurred during the Middle-Late Cenomanian, preceding the organic-rich sedimentation of the OAE2. The age of this deposition was determined based on the radiolarian and foraminiferal datum events (Bak M. et al. 2005; Bąk K. 2007a, c; Bąk M. 2011). It was also confirmed by the carbon isotope data from this succession (Bąk K. 2007a, c; Bąk M. 2011).

\section{Material and methods}

Location of the sections studied. - The studied area is situated in the central part of the Silesian Nappe (Fig. 1A), within the Lanckorona-Żegocina tectonic zone, built of Cretaceous sediments (Fig. 1C). The Mikuszowice Cherts, as the most resistant rocks, create the Barnasiówka Ridge, which is a part of the Wieliczka Foothills in the Western Carpathians (Fig. 1B).

Samples for these studies were collected to supplement sampling for previous studies carried out herein (Bąk K. et al. 2001; Bąk M. 2000, 2004, 2011; Bąk M. et al. 2005, 2011) from two continuous sections that occur 3.5-5 km west of Myślenice town, in two quarries at the Barnasiówka Ridge (Fig. 1C). The first of these quarries, the Barnasiówka-Jasienica quarry, is located on the SW slope of one of the tributaries of Bysina Creek, at an altitude of approximately $520 \mathrm{~m}$. This section includes the upper part of the Middle Lgota Beds, the whole succession of the Mikuszowice Cherts, and the lower part of the overlying BRSF (Fig. 3). The second section outcrops at the Ostra Góra quarry, located on SW slope of Ostra Góra Hill, at an altitude of approximately $500 \mathrm{~m}$, west of the Safiana creek. This section includes the upper part of the Mikuszowice Cherts and their transition to the BRSF (Fig. 3). One of the quarries - the Barnasiówka-Jasienica quarry - was reactivated, providing a new possibility for sampling the continuous outcrop.

Methods. - Samples for micropalaeontological analyses were collected from each stratum (i.e., every 5-20 cm). Microfossils (sponge spicules, radiolarians, foraminifers, echinoid spines) were extracted from each type of sediments as siliciclastics and silicified carbonates. They were picked from fractions above $0.63 \mu \mathrm{m}$. The microfacies and microfossils were also determined in 40 thin sections, made from 20 selected samples of the rocks (Fig. 3).

Microfaunal slides with microfossils are housed in the Faculty of Geology, Geophysics and Environmental Protection, AGH University of Science and Technology.

\section{Isolated sponge spicules in turbidite layers}

Isolated spicules (Figs 5, 6) are present in samples from the uppermost part of the Middle Lgota Beds and the whole section of the Mikuszowice Cherts, and they gradually disappear within the lower part of the BRSF. Their number significantly increases in the middle and upper parts of the Mikuszowice Cherts.

Demospongiae spicules prevail in the assemblages (Figs 5, 6). Only a few spicules of hexactinellids, in the form of hexactines and hexasters, have been found there. The most common spicules are desmas, which are usually moderately to poorly preserved. Some of the better preserved desmas could be assigned as tetraclones and dicranoclones (Figs 5A-I, 6A). Less common in the assemblage are prodichotriaenes, dichotriaenes and phyllotriaenes (Figs 5J-P, T-V, 6B-G, J). Oxeas are also frequent (Figs 5R, 6H). Criccorhabds (Fig. 5S) and dermal discoid spicules (Fig. 5W) are present but rare.

Many of the desmas resemble dicranoclones or tuberculate tetraclones (Fig. 5D, E, H), which can be attributed to the family and genus levels. Tuberculate tetraclones that occur in the sample residue resemble those from the family Theonellidae Lendenfeld, 1903 (Pisera \& Lévi 2002d) and desmas from the genus Acrochordonia Schrammen, 1901 (e.g., Hurcewicz 1966), which are included in the suborder Dicranocladina Schrammen, 1924 (Hooper et al. 2011). 

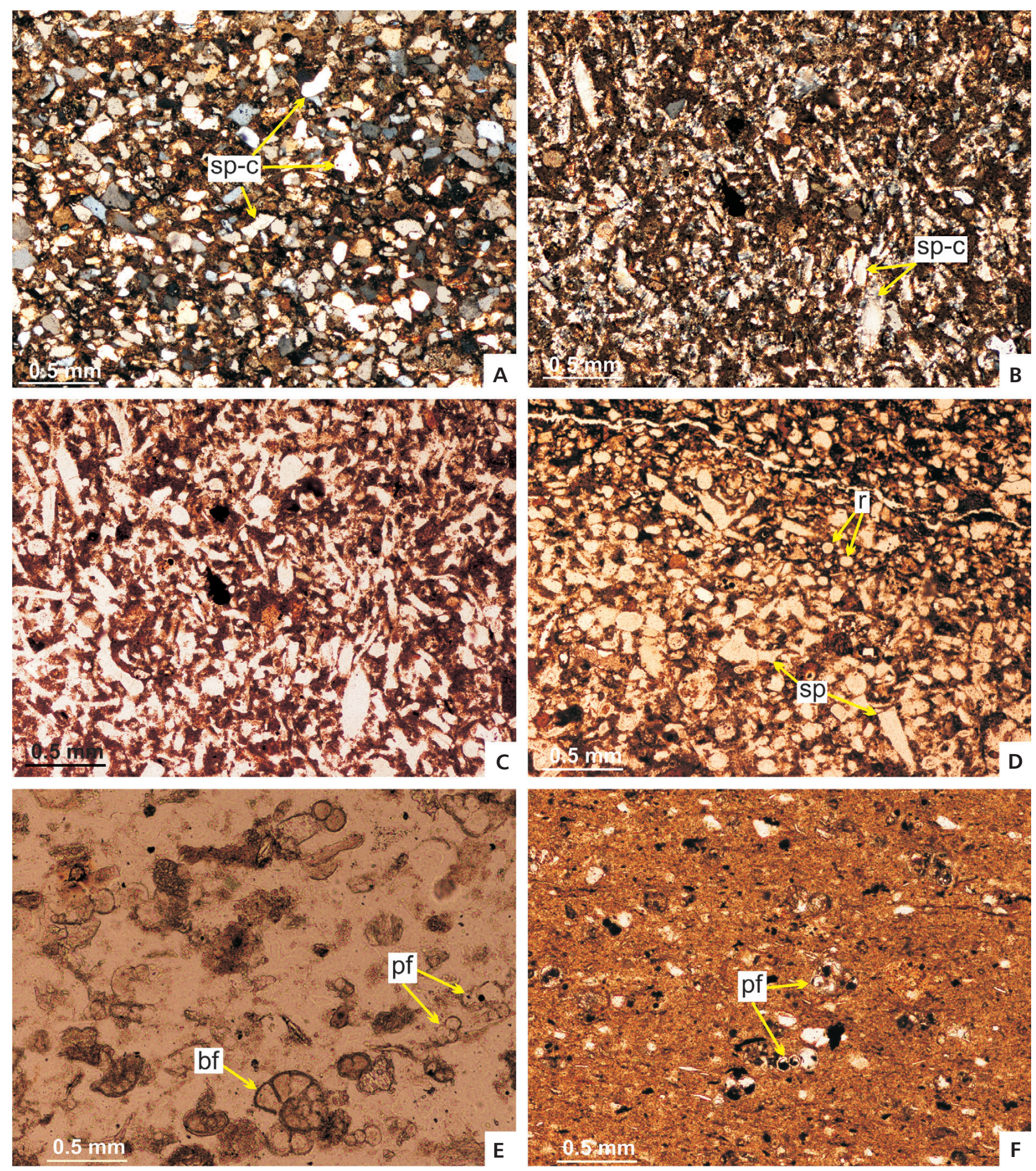

Figure 4. Example of sequence of microfacies in a single turbidite layer (the Bouma sequence), resulted from current segregation from the upper part of the Mikuszowice Cherts. $\bullet$ A - sublitharenite with minor admixture of strongly disintegrated and rounded calcified sponge spicules (sp-c). $\bullet$ B - spiculitic sublitharenite with prevailing calcified sponge spicules (sp-c). $\bullet \mathrm{C}-$ spiculite. $\bullet \mathrm{D}-$ spiculite with numerous radiolarians $(\mathrm{r})$; sp $-\mathrm{sponge}$ spicules. - E - biomicrite with planktonic (pf) and benthic (bf) foraminifers. $\bullet \mathrm{F}-$ foraminiferal wackstone with rare planktonic foraminifers (pf). A-D - sample Bar-1, E, F - sample Bar-12.

They can also be assigned to the family Phymatellidae Schrammen, 1910 (Pisera \& Lévi 2002c). Some of the dicranoclones (Fig. 5H) are typical of the family Corallistidae Sollas, 1888 (Pisera \& Lévi 2002a); however, 
they could also represent the suborder Dicranocladina Schrammen, 1924 of the order Tetralithistida LagneauHerenger, 1962 (see Hooper et al. 2011). Tetraclones with rings on clones (Fig. 5G) are characteristic only for the family Phymaraphiniidae Schrammen, 1910 (for comparison see Pisera \& Lévi 2002b). Phyllotriaenes (Fig. 5J) are characteristic of lithistids from suborder Tetracladina Zittel, 1878 but also of the family Phymaraphiniidae Schrammen, 1924 and the family Theonellidae Lendenfeld, 1903 (see taxonomic subdivision according to Hooper et al. 2011). The presence of sponges from Tetracladina may also be confirmed by dichotriaenes, such as those illustrated in Fig. 5M; however, such spicules could also belong to sponges from other groups, such as suborder Megamorina Zittel, 1878 (see classification scheme after Hooper et al. 2011), or could be derived from some soft demosponges.

Numerous oxeas present in the studied material are visible predominantly in microfacies view (Fig. 4). In the loose residue after rock dissolution, oxeas are less common (Fig. 5). The oxeas may be derived from disintegration of some lithistids, but they are most probably derived from soft demospongae and indicate that sponges from this group were also numerous in the described assemblage. Several criccorhabds found in the investigated material probably belong to the clionids (Hadromerida Topsent, 1928) and thus also represent soft demosponges (Wiedenmayer 1994). Spiny triaens, such as those present in the studied samples (Fig. 5U), occur in the family Thrombidae Sollas, 1888, which is also a group of soft demosponges (see Uriz 2002). Such triaens may also occur in the suborder Dicranocladina Schrammen 1924; however, they should be smaller in that case (Reid 2004). Dermal discoid spicules with strongly incised margins (Fig. 5W) represent pinakid-type spicules assigned here to the genus Dactylocalycites Carter based on similarity to spicules described from Cenomanian deposits of England (Carter 1871) and included in incertae sedis Astrophorida (see Łukowiak 2015).

Spicules represent the three main types of preservation (Fig. 6), which have been observed in the Mikuszowice Cherts (see also Bąk M. et al. 2011). They are 1) recrystallized (Fig. 6H, K, L), 2) replaced by coarse calcite sparite (Fig. 6C, D, F, G), and 3) replaced by blocky calcite (Fig. 6A, B, E, J). Spicules replaced by a different type of calcite are present commonly within the lithotypes where the amount of spicules does not exceed $10 \%$ of grains. In such lithofacies, it is the only type of sponge spicule preservation (Fig. 6A-G). In the spicule-rich sediments, spicules replaced by calcite are less common or absent and are usually broken and rounded by transportation.

\section{Middle-Late Cenomanian sponge communities}

Based on the detritic and biogenic components occurring in the Middle-Upper Cenomanian turbidites of the studied succession and following the present day examples of huge sponge colonies found on the Western Canadian shelf, the Florida Straits (Neumann et al. 1977), and the Rockall Trough in the NE Atlantic Ocean (Van Weering et al. 2003), we speculate that this mass of spicule material originated from growth and destruction of numerous sponge associations that formed on shelves mainly by lithistids and soft demosponges. An important phenomenon, which occurred at least partially in such an environment, was an early calcitization of siliceous sponge spicules. This process is confirmed here based on an existence of micritic clasts (1-2 mm across) found in the studied turbidites (Fig. 7C-E), which contain calcified spicules. Moreover, most of the Cretaceous lithistids lived on mud bottoms (see, e.g., Świerczewska-Gładysz 2006). The early calcitization of isolated sponge spicules might have occurred very early, during the initial decay and/or early burial in soft, non-lithified mud, which is known from modern and ancient shelves, especially in shallow-water environments including spiculitic carbonate mud-mounds and reefs (e.g., Land 1976, Wiedenmayer 1980, Reitner \& Keupp 1991, Reitner 1993, Hammes 1995, Reitner et al. 1995, Warnke 1995, Pisera 1997, Kauffman et al. 2000, Neuwailer \& Burdige 2005). A few authors have reported this process as proceeding even during the sponge's life and during its decay in a few-centimetres-thick layer of weakly cemented material associated with bacterial mats (Froget 1976, Pratt et al. 1986, Bavestrello et al. 1996, Neuweiler \& Burdige 2005). The early cementation of calcareous mud containing sponge spicules is also confirmed here by a presence of remnants of bacterial crusts, which are visible as disintegrated particles in the turbiditic sediments. Such crusts supported binding and stabilization of calcareous mud, which surrounded hypothetical sponge associations (Bąk M. et al.

Figure 5. Selected Demospongiae spicules obtained from spiculite and spiculitic sublitharenite in the uppermost part of the Mikuszowice Cherts. - A, B, I - poorly preserved desmas. • C - fragment of desma (clone with zygosis) - probably tetraclone. • D, E, H - dicranoclones or tuberculate tetraclones. - F - dicranoclone typical for family Corallistidae Sollas, 1888 . $\bullet \mathrm{G}$ - tetraclone with rings on clones characteristic only for family Phymaraphiniidae Schrammen, 1910. • J - ectosomal phyllotriaene. • K-P - ectosomal dichotriaenes. • R - style, smooth type, probably part of exotylostyle. $\bullet \mathrm{S}$ - criccorhabd. $\bullet \mathrm{T}, \mathrm{V}-$ massive prodichotriaene. $\bullet \mathrm{U}-$ massive dichotriaene with spiny clads. $\bullet \mathrm{W}-\mathrm{ectosomal}$ discoid spicule of pinakid type, with strongly incised margin. $\bullet Y-$ oxyspheraster. Sample Bar-5. Scale bars $100 \mu \mathrm{m}$. 


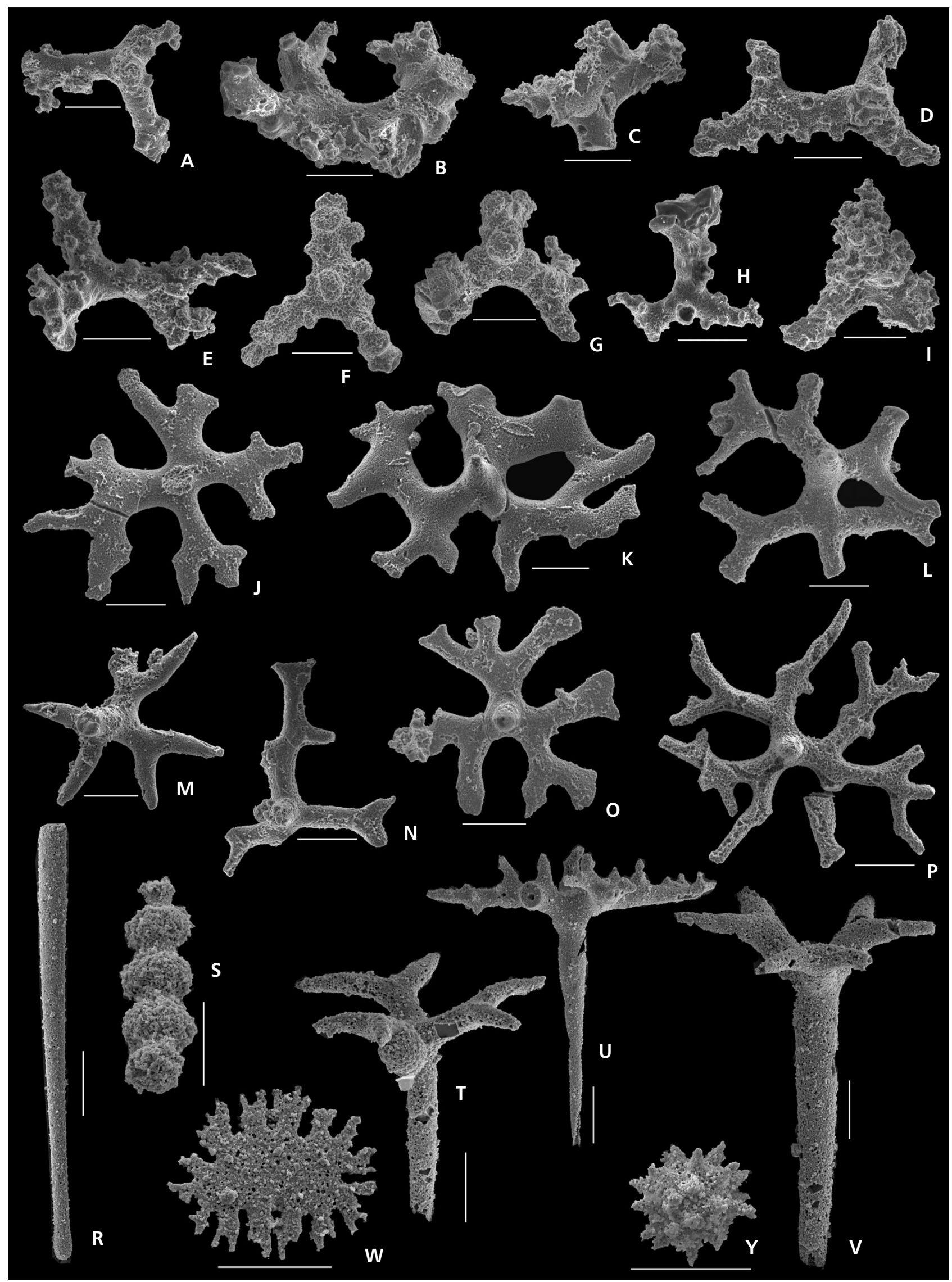


2015). The area with a dense population of sponges (mainly demosponges) might also have been covered by terrigenous sands and by firm substrate resulting from winnowing of sediment by bottom currents. Such places were essential to further colonization by sponges, which need such a firm substrate to attach larvae (Krautter et al. 2001).

The carbonate particles and micrite are other components of the turbidites in the studied area (see Bąk M. 2000; Bąk M. et al. 2005, 2011). Their presence indicates that the ancient shelves that surrounded the Silesian Basin were predominantly covered by calcareous mud and received fine-grained authigenic calcium carbonate. The presence of a soft micritic substrate may also be confirmed by the occurrence in the turbidites of redeposited calcareous benthic foraminifers, which preferred such types of sediment during their life. The calcareous benthos occurs in each studied turbidite layer (Bąk M. et al. 2005). Among the diversified assemblages, some species (e.g., Gavelinella baltica Brotzen) were restricted to marly facies, while others favoured life conditions on both calcareous and silty sediments [Berthelina berthelini (Keller), Lingulogavelinella globose (Brotzen); summary in Hradecká 1993].

Many of the bioclasts in turbidites possess a micritic envelope with microborings (Fig. 6I). The original microstructure of these grains has usually been obliterated by later diagenetic processes, but the micritic envelopes and prismatic fringe cements maintain the original shape of the skeletal grains. Microborings are developed on calcified demosponge spicules in the studied material (Fig. 6I), which confirms the earliest calcitization of these spicules and subsequent colonization of calcitized spicules as calcareous grains by bacteria. Microborings also occur on other carbonate bioclasts and intraclasts in the studied turbidites (Fig. 7A, B). In conclusion, the microborings developed on various carbonate clasts may suggest that this process occurred before delivery of these particles into turbidite sediments, on shelves covered by calcareous, muddy sediments.

\section{Depth of sponge associations}

Spicules of the sponges recognized in the turbidite layers do not allow for precise bottom depth assessment. Lithistids, which dominate in shelf sediments from the Northern European Platform, correspond to water conditions rather than to the depth of the seas (Termier \& Termier 1980). Relatively diverse lithistids are known from the Early Cretaceous glauconitic facies of Spain, southern France, and England (Reid 1962, Wiedenmayer 1980, Reitner 1987) and from the Late Cretaceous of the European epicontinental seas (e.g., Hinde 1883, Schrammen 1910-1912, Moret 1926, Nestler 1961, Reid 1962, Hurcewicz 1966). Lithistid assemblages, although rarely recognized, are present in
Cretaceous sub-Tethyan settings. The exceptions are regions located on the marine platforms bordering the Tethyan basins to the north, with possible communication with the Western Tethys during sea-level rise episodes. Such an example was presented from the Regensburg area in Germany by Kauffman et al. (2000).

Cretaceous soft demosponges were previously described by Schrammen (1910) and Hurcewicz (1968). The most important component of the Late Campanian and Early Maastrichtian opokas are loose spicules of soft demosponges (most likely belonging to the order Astrophorida Sollas, 1888; see Hooper \& Van Soest 2002, Pisera et al. 2006, Świerczewska-Gładysz 2012).

Recent demosponges are found mainly on the intrabasinal plateaus and shelves surrounding the continents at water depths from very shallow down to approximately $600 \mathrm{~m}$ (Lévi 1991). In contrast, hexactinellid sponges, of which rare spicules also occur in the studied turbiditic material, are commonly found in deep ocean and cold-water habitats (e.g., Rice et al. 1990, Lévi 1991); however, they are also present in shallow and warm environments (e.g., Gammon et al. 2000) but usually under special conditions (e.g., Whitney et al. 2005). It should be stressed that the main controlling factor in the distribution of lithistid versus hexactinellid sponges in geological records and present-day communities is not bathymetry but the predominant type of food availability and sedimentation rate (Pisera et al. 1992, Pisera 1997, Krautter 1997, Duarte et al. 2001). Demosponges are able to live associated, either commensally or symbiotically, with bacteria or on the metabolic products of the bacteria. Bacterial symbionts may play a role in the acquisition and defence of their host sponge (Hentschel et al. 2001). Sponges may harbour large amounts of bacteria in their tissues that can amount to $40 \%$ of their biomass (Vacelet 1975). Therefore, the bathymetric distribution of filter feeding demosponges varies considerably in the water column.

The calcareous benthic foraminiferal assemblages, numerous in the redeposited intervals of turbidites, are more important for depth estimation of which sponge associations could thrive. These assemblages are dominated by small forms belonging to gavelinellids and the genus Gyroidinoides, which is associated, among others, with Lenticulina, Praebulimina and Dentalina (Bąk M. et al. 2005, 2011). Taxa resembling these from outer distal ramp facies, with water depth of 150-300, and their transition to upper slope facies were described from the Cenomanian deposits of the Basque-Cantabrian Basin, the northern continental margin of the Iberian Plate (Gräfe 2005). Similar Cenomanian assemblages, dominated by gavelinellids, were described in the southern part of the European Platform in both the calcareous (Polish Lowlands: Gawor-Biedowa 1972, Heller 1975, Peryt 1983) and the siltstone facies (Bohemian Cretaceous Basin: Hradecká 

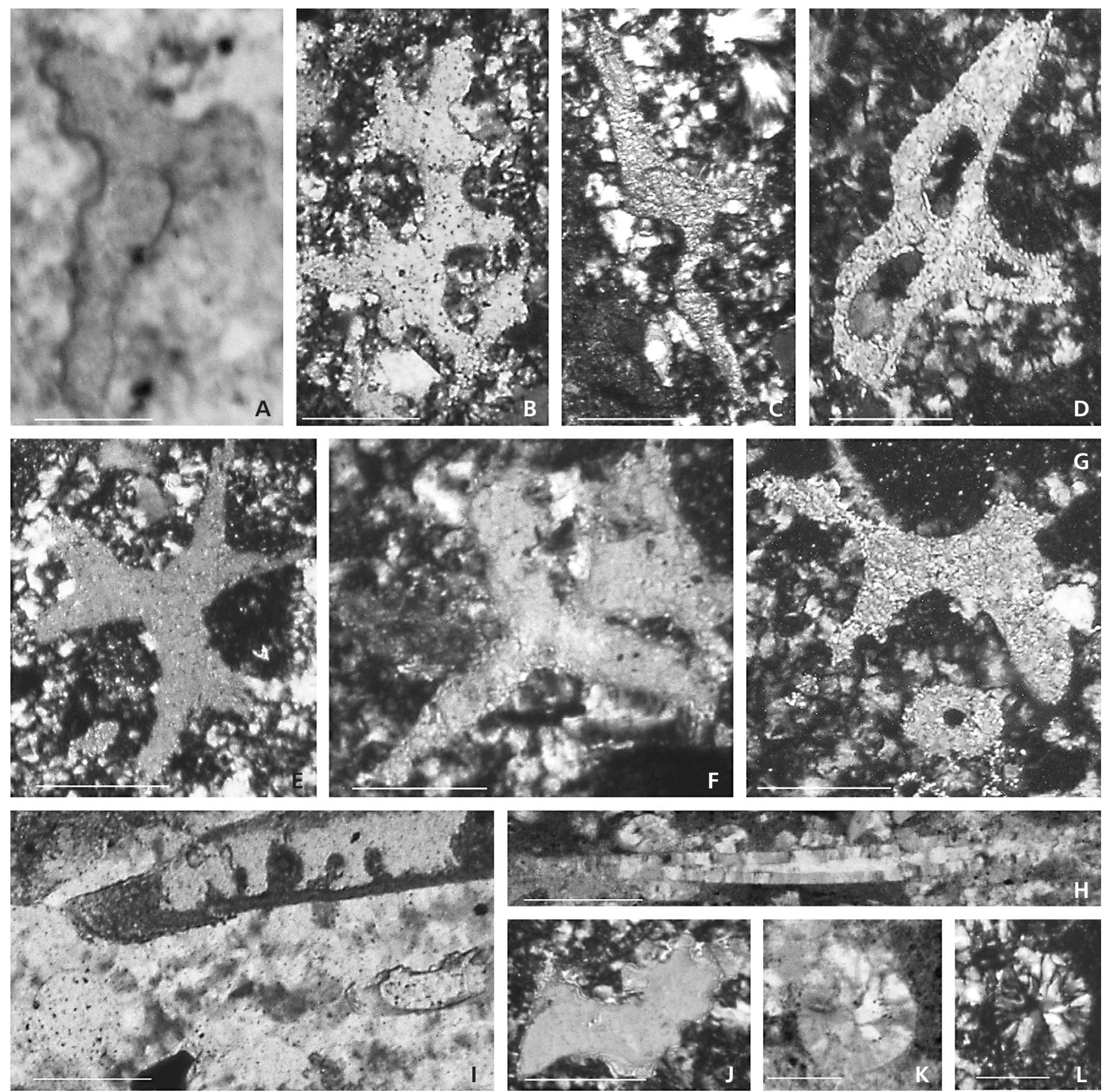

Figure 6. Preservation of sponge spicules from spiculite and spiculitic sublitharenite in the Mikuszowice Cherts. $\bullet$ A - desmas replaced by blocky calcite (singular crystal). $\bullet \mathrm{B}, \mathrm{E}, \mathrm{J}-$ ectosomal spicules of demosponges replaced by blocky calcite. $\bullet \mathrm{C}, \mathrm{D}, \mathrm{F}, \mathrm{G}-$ ectosomal spicules of demosponges replaced by coarse, fringe spar. $\bullet$ I sponge spicule replaced by blocky calcite (singular crystal) with intensively micritized lower edge; microscopic bores are filled with micritic cement. $\bullet \mathrm{H}, \mathrm{K}, \mathrm{L}-$ sponge spicules (originally siliceous) recrystallized into microcrystalline quartz; spicule's central canal filled with blocky calcite (singular crystal). A - sample Bar-5, B, J - sample Bar-18, C, E, F - sample Bar-63, D, G, I - sample - Bar-57, H, K, L - sample Bar-51. Scale bars $100 \mu \mathrm{m}$.

1993, Hradecká \& Švábenická 1995). They are also abundant in the calcareous facies (marls) of the northwest and southeast European continental shelves (e.g., Hart \& Swiecicki 1988, Dubicka \& Peryt 2014).

Other indicators of relatively "shallow-water" depths (neritic depths) of the studied source area for microfossils occurring in the turbidite sediments are strongly impover- ished assemblages of "keeled" planktonic foraminifers (praeglobotruncanids and rotaliporids; Bąk M. et al. 2005), which are interpreted as deep-dwellers during mid-Cretaceous times (Hart 1980, Leckie 1987). However, it should be stressed that these foraminifers could be eliminated by many other environmental factors related to the expanded oxygen minimum zone during the Late Cenomanian. 

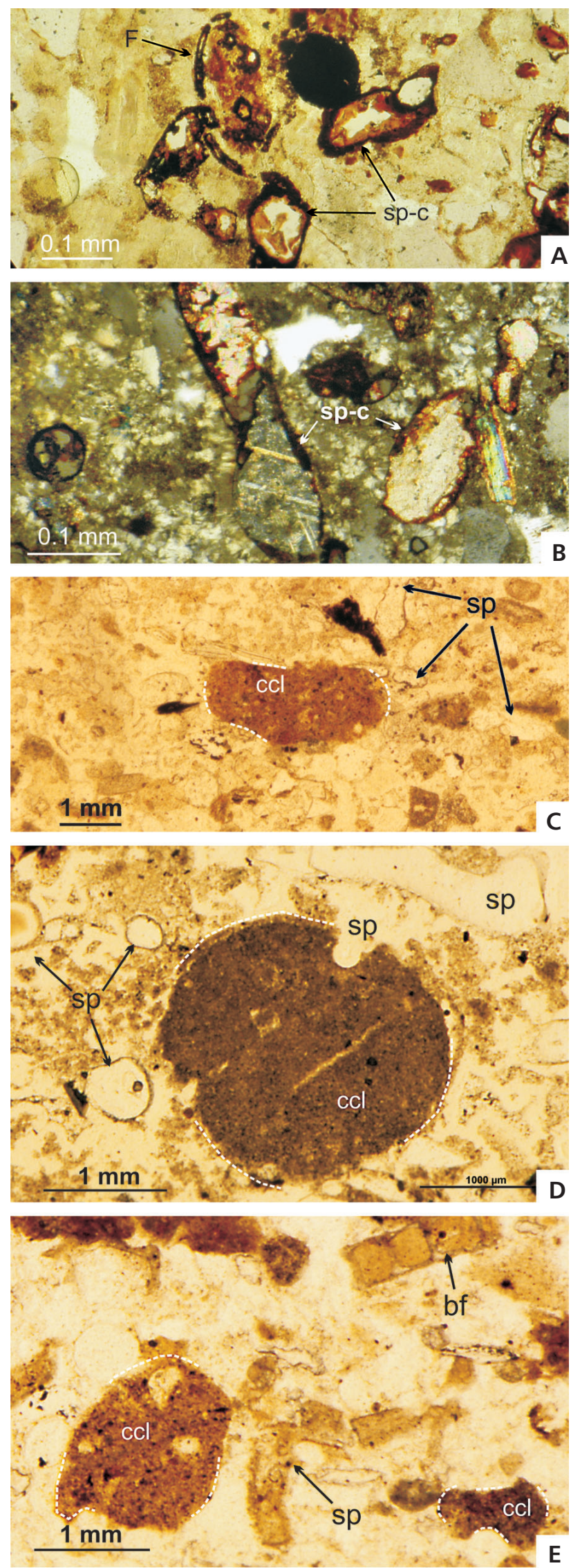

Neritic depths for derivation of redeposited biogenic particles can also be confirmed by the presence of glauconite grains occurring in several beds of the turbidite sandstones, especially in the upper part of the studied succession (Fig. 8B). Glauconite is thought to form on the open continental shelf and upper slope at water depths of 15-500 m (Rothwell 1989).

Summing up, the composition of redeposited biogenic and inorganic grains in the studied turbidite layers suggests that during the Middle-Late Cenomanian, the shelf with numerous sponge communities, as the marginal part of the West European Platform, may have possessed diverse topographic relief, with depths ranging between tens to several hundred metres.

\section{Nutrient supply for sponge growth}

The development of sponge assemblages requires balanced delivery of sediment particles that are effectively trapped by sponges and waters enriched with nutrients (e.g., Whitney et al. 2005). Present-day demosponges rely directly on particulate matter (Krautter 1997). The major nutrient limitation for the modern sponge fauna is the usable dissolved silica content in the oceanic water (Maldonado et al. 1999). Silica can be delivered from terrestrial chemical weathering under low erosional rates and fine-grained sediment supply. Such favourable conditions occurred on the southern European shelves, including the area near the northern margin of the Carpathian basins, during the Late Cenomanian transgression (e.g., Miller et al. 2005, Haq 2014), which entered a low-gradient plain that formed after the Early Cretaceous lowstand (Marek 1988). The development of sponge associations in such plains during the Middle-Late Cenomanian lasted approximately $2 \mathrm{Ma}$, based on correlation of radiolarian and foraminiferal zones with chronostratigraphy ( $c f$. Bąk M. et al. 2005, Bąk M. 2011). Data from the Anglo-Paris and Saxony basins (Voigt et al. 2007) show that the rise of sea level at high latitudes was rapid. It occurred with two pulses during the M. geslinianum Ammonite Zone. High sea levels caused temporary connection of the Tethyan realm with epicontinental basins and initiated sponge colonization due to conditions favour-

Figure 7. Redeposited calcareous clasts in the microfacies view of the Mikuszowice Cherts. - A - fragment of planktonic foraminiferal test (F) coated by micritic/Fe envelope; (sp-c) -cross-section by calcified sponge spicules which were previously rounded and then covered by micritized cover of bacterial origin. - B - another example of calcareous grains, which are predominantly calcified spicules of sponges (sp-c) with micritized surface. Micrite cement fill in the microborings, which are in bacterial size. $\bullet \mathrm{C}-\mathrm{E}$ - calcareous clasts ( $\mathrm{ccl}$ ) in spiculitic sublitharenite of various turbidite layers; sp - calcified sponge spicule, bf - benthic foraminifer. A, B - sample Bar-5, C-sample Bar-18, D - sample Bar-63. 


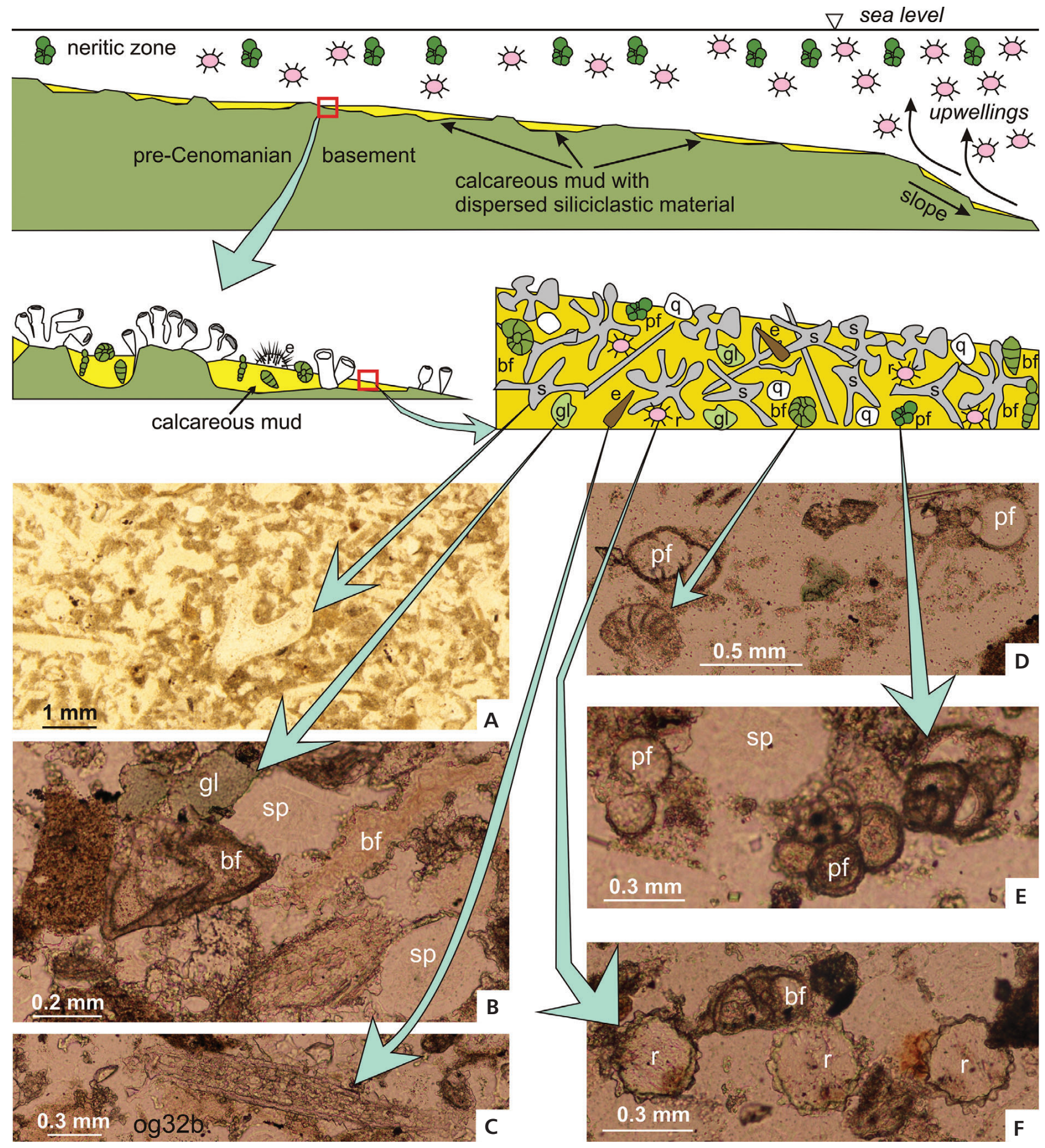

Figure 8. Key features of redeposited particles in the Middle-Upper Cenomanian turbidites of the Silesian Nappe, Polish Outer Carpathians, coming from neritic zone of the shelves and upper slopes of the Silesian Basin. Abbreviations of fossils in neritic zone: e - echinoid spine, bf - benthic foraminifer, pf-planktonic foraminifer, $\mathrm{r}$-radiolarian, s - sponge spicule. A - sample Bar-32, B, F- sample Os-2, C-sample Bar-32, D-sample Os-12, E - sample Os-11.

able to their development. An alternative source of silica that could be successfully used especially by demosponges might be opal grains, such as radiolarian tests or diatom frustules, suspended in the water column during blooms of siliceous plankton. Recently conducted experiments (Bavestrello et al. 2003) showed that several species of demosponges could effectively select the material incorporated into their soft tissue. Sponges incorporate only siliceous 
materials, particularly quartz and opal grains, avoiding carbonate particles. The opal particles remain unaltered within the sponge tissue, but quartz particles are quickly etched, reduced in size, and released from the sponge. Such processes might be responsible for the delivery of silica into sponge associations, at least during the Middle-Late Cenomanian, taking into account the co-occurrence of numerous radiolarians and sponge spicules in the studied material. As a consequence, demosponges did not compete for dissolved silicon with siliceous plankton, but rather, their growth was supported by the development of siliceous plankton. It is even possible that blooms of radiolarians may have stimulated sponge growth during this time. Such blooms could be related to seasonal upwellings, whose occurrence during the Middle-Late Cenomanian is here speculated on the basis of some radiolarian species, such as Holocryptocanium barbui Dumitrica and $H$. tuberculatum Dumitrica, typical of environments with increased productivity (for details of their ecology see Bąk M. 2011).

\section{Abundant sponge communities along the northern edge of the Carpathian basins}

The flute casts developed on the thick bed soles of the studied turbidites indicate a north-west direction of the gravity currents, which transported the spiculitic and other biogenic material to the deep sea floor ( $c f$. Książkiewicz 1962, Unrug 1977). These directions indicate that the source of redeposited material to the Silesian Basin was situated on the southern margin of the West European Platform, which is currently thrust over by the Carpathian nappes. Data on the Cenomanian palaeogeography and facies development of this marginal part of the European Platform have been reconstructed based on numerous boreholes (see discussion in Jaśkowiak-Schoeneichowa \& Krassowska 1988, Kutek 1994, Moryc 1997, Gutowski et al. 2005). According to these data, the source area was characterized by extensive shelves during a long period lasting since the Late Jurassic and temporarily connected with the epicontinental seas of Western and Central Europe. The possible routes of these connections in the Polish part might have been a prolongation of several depressions and furrows situated along the southern border of the epicontinental basins (Jaskowiak-Schoeneichowa \& Krassowska 1988).

The most adequate equivalent to the sponge associations that were the source area for spiculite-bearing turbidites in the Mikuszowice Cherts are the sponge associations described near Regensburg in Germany (Kaufmann et al. 2000), which developed during the Middle and Upper Cenomanian in the region known palaeogeographically as the Gulf of Regensburg. Development of sponges in this area was interpreted as related to the Cenomanian transgression onto the southern European shelves with the for- mation of a marine linkage between the Gulf of Regensburg and Mediterranean Tethys.

The sponge spicules do not occur in the uppermost Cenomanian-lowermost Turonian diluted turbidites in the Silesian Nappe of the studied area (Bąk K. 2006, 2007a, b; Back M. 2011). This is related to changes in basinal circulation and expansion of the oxygen minimum zone on the shelves corresponding to the OAE2 from one side and to a high-stand of sea level (compare Haq 2014) from the second side, which limited the supply of material from the shelves to the deep basins. Numerous sponge spicules appeared again among the siliciclastic fine-grained particles in the turbidity currents flowing to the Silesian Basin during the Middle Turonian, as was documented from the study of the Variegated Shale in this region (Okoński et al. 2014). Most likely, the spicules were derived from unconsolidated material accumulated earlier in various parts of the basin slopes, from which they were exhumed and again redeposited by turbidity currents during those times.

\section{Conclusions}

The Mid-Cretaceous was a period of sponge growth in epicontinental seas and, correspondingly, a period of accumulation of spicule-rich turbidites in the deep basins of the Outer Carpathians, which are situated along the southern edge of the West European Platform. Their deposition in the Silesian Basin lasted $2 \mathrm{Ma}$, during the Middle-Late Cenomanian, preceding the organic-rich sedimentation of the Oceanic Anoxic Event 2.

Based on the detritic and biogenic components of turbidites, we interpret that such masses of spicule material may originate on shelves from the growth and destruction of organic sponge associations, which are composed and stabilized by intensive sponge development and accompanied by occurrence of other benthic microfauna and bacteria. The sponge associations were dominated by forms from three orders of Demospongiae, namely, Lithistida, Hadromerida and Astrophorida.

The bottoms of the shelves colonized by sponges were covered mainly by calcareous mud (micrites). In such environments, spicules of sponges underwent fast diagenetic calcitization. After that they were destroyed, abraded and transported by water currents on the shelf. During that time, some of them were also microbored by bacteria. The concomitant calcareous benthic foraminiferal assemblages indicate that sponge associations may have grown in the outer distal shelf and transition to the upper slope.

The occurrence of numerous radiolarian skeletons together with sponge spicules in the turbidites and their large number in the pelagic sediments of the studied succession carries information about the possible source of silica that is successfully used by demosponges. The blooms of radio- 
larians, which are related to seasonal upwellings on the northern margin of the Carpathian basins during the Middle-Late Cenomanian, are speculated to have occurred on the basis of the abundant occurrence of some radiolarian species (H. barbui and H. tuberculatum) typical of environments with increased productivity and may have stimulated sponge growth during this time.

\section{Acknowledgements}

Two reviewers: Claudia C. Johnson and Ewa Świerczewska-Gładysz are greatly appreciate for their valuable comments, which improve and clarify the previous version of the manuscript. This paper was supported by Funds of Pedagogical University of Cracow and AGH University of Science and Technology awarded to K. Bąk (DS UP-WGB No 4n) and to M. Bąk (DS-AGH WGGiOŚ-KGOiG No 11.11.140.173).

\section{References}

AleXANDrowicz, S.W. 1973. Gaize-type sediments in the Carpathian flysch. Neues Jahrbuch für Geologie und Paläontologie, Monatschefte 1, 1-17.

Bavestrello, G., Cattaneo-Vietti, R., Cerrano, C. \& Sarà, M. 1996. Spicule dissolution in living Tethya omanensis (Porifera: Demospongiae) from a tropical cave. Bulletin of Marine Science 58, 598-601.

Bavestrello, G., Benatti, U., Cattaneo-Vietti, R., Cerrano, C. \& Giovine, M. 2003. Sponge cell reactivity to various forms of silica. Microscopy Research and Technique 62, 327-335. DOI 10.1002/jemt.10399

BÁ, K. 2006. Sedimentological, geochemical and microfaunal responses to environmental changes around the Cenomanian-Turonian boundary in the Outer Carpathian Basin; a record from the Subsilesian Nappe, Poland. Palaeogeography, Palaeoclimatology, Palaeoecology 23, 335-358.

DOI 10.1016/j.palaeo.2005.12.008

BÁ, K. 2007a. Deep-water facies succession around the Cenomanian-Turonian boundary in the Outer Carpathian Basin: Sedimentary, biotic and chemical records in the Silesian Nappe, Poland. Palaeogeography, Palaeoclimatology, Palaeoecology 248, 255-290.

DOI 10.1016/j.palaeo.2006.12.005

BАК, K. 2007b. Organic-rich and manganese sedimentation during the Cenomanian-Turonian boundary event in the Outer Carpathian Basin, a new record from the Skole Nappe, Poland. Palaeogeography, Palaeoclimatology, Palaeoecology 256, 21-46. DOI 10.1016/j.palaeo.2007.09.001

BÅK, K. 2007c. Environmental changes during the Cenomanian-Turonian boundary event in the Outer Carpathian basins: a synthesis of data from various tectonic-facies units. Annales Societatis Geologorum Poloniae 77, 171-191.

BĄK, K., BĄK, M. \& PAUL, Z. 2001. Barnasiówka Radiolarian Shale Formation - a new lithostratigraphic unit in the Upper Cenomanian-lowermost Turonian of the Polish Outer
Carpathians. Annales Societatis Geologorum Poloniae 71, 75-103.

BǍ, M. 2000. Radiolaria from the Upper Cenomanian-Lower Turonian deposits of the Silesian Unit (Polish Flysch Carpathians). Geologica Carpathica 51, 309-324.

BÁ, M. 2004. Radiolarian biostratigraphy of the Upper Cenomanian-Lower Turonian deposits in the Subsilesian Nappe (Outer Western Carpathians). Geologica Carpathica $55,239-250$.

BÅK, M. 2011. Tethyan radiolarians at the Cenomanian-Turonian Anoxic Event from the Apennines (Umbria-Marche) and the Outer Carpathians: Palaeoecological and palaeoenvironmental implications. Studia Geologica Polonica 134, 7-279.

BĄK, M., BĄK, K. \& CiUREJ, A. 2005. Mid-Cretaceous spiculerich flysch deposits in the Silesian Nappe of the Polish Outer Carpathians; radiolarian and foraminiferal biostratigraphy. Geological Quarterly 49, 275-290.

BĄ, M., BĄK, K. \& CiUREJ, A. 2011. Palaeoenvironmental signal from the microfossils record in the Mikuszowice Cherts of the Silesian Nappe, Polish Outer Carpathians, 15-25. In BĄ, M., KAMINSKI, M.A. \& WAśKowsKA, A. (eds) Integrating Microfossil Records from the Oceans and Epicontinental Seas. Grzybowski Foundation Special Publication 17. 144 pp. Grzybowski Foundation, Kraków.

BĄ,, M., BĄK, K., GóRny, Z., StożeK, B. \& Wolska, A. 2015. Evidence of bacteriogenic iron and manganese oxyhydroxides in Albian-Cenomanian marine sediments of the Carpathian realm (Poland). Annales Societatis Geologorum Poloniae 85(2), 371-385.

Birkenmajer, K. 1986. Stages of structural evolution of the Pieniny Klippen Belt, Carpathians. Studia Geologica Polonica 88, 7-32.

BRYNDAL, T. 2014. A method for identification of small Carpathian catchments more prone to flash flood generation. Based on the example of south-eastern part of the Polish Carpathians. Carpathian Journal of Earth and Environmental Sciences 9, 109-122.

Burtan, J. (ed.) 1964. Detailed Geological Map of Poland in scale 1:50,000 (without Quaternary sediments); the Carpathian and Fore-Carpathian area: Myślenice sheet. Wydawnictwa Geologiczne, Warszawa.

Burtan, J. \& SzymakowsKa, F. (eds) 1964. Detailed Geological Map of Poland in scale 1:50,000 (without Quaternary sediments); the Carpathian and Fore-Carpathian area: Osielec sheet. Wydawnictwa Geologiczne, Warszawa.

CARTER, H.J. 1871. On fossil sponge-spicules of the Greensland compared with those of existing species. Annals and Magazine of Natural History, Series 4, 7(38), 112-141.

Defretin-Lefranc, S. 1960. Contribution à l'étude des spongiaires siliceux du Crétacé supérieur du Nord de la France. Thèses à la Faculte des Sciences de Lille 1958, 1-178.

Duarte, L.V., Krautter, M. \& Soares, A.F. 2001. Bioconstructions à spongiaires siliceux dans le Lias terminal du Bassin lusitanien (Portugal): stratigraphie, sédimentologie et signification paléogéographique. Bulletin de la Société géologique de France 172, 637-646. DOI 10.2113/172.5.637

Dubicka, Z. \& Peryt, D. 2014. Classification and evolutionary interpretation of late Turonian-early Campanian Gavelinella and Stensioeina (Gavelinellidae, benthic foraminifera) from 
western Ukraine. Journal of Foraminiferal Research 44, 151-176. DOI 10.2113/gsjfr.44.2.151

Froget, C. 1976. Obsérvations sur l'altération de la silice et des silicates au cours de la lithification carbonatée (Région Siculo-Tunisienne). Géologie Méditerréenne 111, 219- 226.

Gammon, P.R., James, N.P. \& PiserA, A. 2000. Eocene spiculites and spongolites in southwestern Australia: not deep, not polar, but shallow and warm. Geology 28, 855-858. DOI 10.1130/0091-7613(2000)28<855:ESASIS >2.0.CO;2

Gawor-Biedowa, E. 1972. The Albian, Cenomanian and Turonian foraminifers of Poland and their stratigraphic importance. Acta Paleontologica Polonica 17, 3-165.

Golonka, J., OszczypKo, N. \& ŚlączKa, A. 2000. Late Carboniferous-Neogene geodynamic evolution and paleogeography of the circum-Carpathians region and adjacent areas. Annales Societatis Geologorum Poloniae 70, 107-136.

GräFE, K.-U. 2005. Late Cretaceous benthic foraminifers from Basque-Cantabrian Basin, Northern Spain. Iberian Geology 31, 277-298.

Gutowski, J., Popadjuk, I.V. \& Olszewska, B. 2005. Late Jurassic-earliest Cretaceous evolution of the epicontinental sedimentary basin of southeastern Poland and Western Ukraine. Geological Quarterly 49, 45-52.

Hammes, U. 1995. Initiation and development of small-scale sponge mud-mounds, Late Jurassic, Southern Franconian Alb, Germany, 335-357. In Monty, C.L.V., Bosence, D.W.J., BRIDGES, P.H. \& PRATT, B.R. (eds) Carbonate mud-mounds: their origin and evolution. International Associations of Sedimentologists Special Publications 23. Blackwell, Oxford.

HAQ, B.U. 2014. Cretaceous isostasy revisited. Global and Planetary Change 113, 44-58.

DOI 10.1016/j.gloplacha.2013.12.007

HaRT, M.U. 1980. A water depth model for the evolution of the planktonic foraminifera. Nature 286, 252-254. DOI $10.1038 / 286252 \mathrm{a} 0$

HART, M.B. \& SwIECICKI, A. 1988. The genus Gavelinella Brotzen, 1942, in the Cretaceous strata of the U.K. Revue Paléobiologie vol. spéc. 2, 289-294.

HeLlER, I. 1975. Microbiostratigraphy of the Cretaceous deposits in the southern part of the Łódź Synklinorium (Central Poland). Annales Societatis Geologorum Poloniae 55, 233-254.

Hentschel, U., Schmid, M., Wagner, M., Fieseler, L., Gernert, C. \& HACKER, J. 2001. Isolation and phylogenetic analysis of bacteria with antimicrobial activities from the Mediterranean sponges Aplysina aerophoba and Aplysina cavernicola. FEMS Microbiology Ecology 35, 305-312. DOI 10.1111/j.1574-6941.2001.tb00816.x

HindE, G.J. 1883. Catalogue of the fossil sponges in the Geological Department of the British Museum. 248 pp. British Museum (Natural History), London.

Hooper, J.N.A. \& VAN SOEST, R.W.M. 2002. Order Astrophorida Sollas, 186-195. In Hooper, J.N.A. \& Van Soest, R.W.M. (eds) Systema Porifera. Kluwer Academics/Plenum Press, New York

Hooper, J.N.A., Van Soest, R.W.M. \& Pisera, A. 2011. Phylum Porifera Grant, 1826, 13-18. In ZHANG, Z.-Q. (ed.) Animal biodiversity: An outline of higher-level classification and survey of taxonomic richness. Zootaxa 3148.

HradeCKÁ, L. 1993. Gavelinella Brotzen, 1942 and Lingulo- gavelinella Malapris, 1969 (Foraminifera) from the Bohemian Basin. Sborník geologických věd, Paleontologie 33, 79-96.

HRADECKÁ, L. \& ŠvÁBENICKÁ, L. 1995. Foraminifera and calcareous nannoplankton assemblages from the Cenomanian-Turonian boundary interval of the Knoviz section, Bohemian Cretaceous Basin. Geologica Carpathica 46, 267-276.

Hurcewicz, H. 1966. Siliceous sponges from the Upper Cretaceous of Poland. Part I. Tetraxonia. Acta Paleontologica Polonica 11, 15-119.

Hurcewicz, H. 1968. Siliceous sponges from the Upper Cretaceous of Poland, Part II, Monaxonia and Triaxonia. Acta Palaeonologica Polonica 13, 3-96.

JAŚKOWIAK-SCHOENEICHOWA, M. \& KrassowsKA, A. 1988. Palaeothickness, lithofacies and palaeotectonics of the epicontinental Upper Cretaceous in Poland. Kwartalnik Geologiczny 32, 177-198.

Kauffman, E.G., Herm, D., Johnson, C.C., Harries, P. \& Efling, R.H. 2000. The ecology of Cenomanian lithistid sponge frameworks, Regensburg area, Germany. Lethaia 33, 214-235. DOI 10.1080/00241160025100071

KosZARski, L. \& ŚlącZKA, A. 1973. Outer (flysch) Carpathians, Lower Cretaceous, 492-495. In PożARysKi, W. (ed.) Geology of Poland. Instytut Geologiczny, Warszawa.

KrautTER, M. 1997. Aspekte zur Paläökologie postpaläozoischer Kieselschwämme. Profil 11, 199-324.

Krautter, M., Conway, K.W., Barrie, J.V. \& Neuweiler, M. 2001. Discovery of a "living dinosaur": globally unique modern Hexactinellid sponge reefs off British Columbia, Canada. Facies 44, 265-282. DOI 10.1007/BF02668178

KsIĄŻKIEWICZ, M. 1951. Explanations to the Wadowice sheet of the Detailed Geological Map of Poland in scale 1:50 000.283 pp. Państwowy Instytut Geologiczny, Warszawa.

KSIĄŻKIEWICZ, M. 1956. Geology of the Northern Carpathians. Geologische Rundschau 45, 396-411.

DOI 10.1007/BF01802022

KsiĄŻKıIEwicz, M. (ed.) 1962. Geological Atlas of Poland; Stratigraphic and Facial Problems, vol. 13. Cretaceous and Older Paleogene in the Polish Outer Carpathians. 20 maps, 20 pp. Instytut Geologiczny, Wydawnictwa Geologiczne, Warszawa.

KsIĄŻKIEWICZ, M. 1977. Hypothesis of plate tectonics and the origin of the Carpathians. Annales Societatis Geologorum Poloniae 47, 329-353.

KuTEK, J. 1994. Jurassic tectonic events in south-eastern cratonic Poland. Acta Geologica Polonica 44, 167-221.

LAND, L.S. 1976. Early dissolution of sponge spicules from reef sediments, North Jamaica. Journal of Sedimentary Petrology 46, 967-969.

LaubenFels, M.W. DE 1955. Archaeocyatha and Porifera, 1-113. In Moore, R.C. (ed.) Treatise on Invertebrate Paleontology. Part E. Geological Society of America \& University of Kansas Press, Boulder \& Lawrence.

LECKIE, R.M. 1987. Paleoecology of mid-Cretaceous planktonic foraminifera: a comparison of open ocean and epicontinental sea assemblages. Micropaleontology 33, 164-176. DOI $10.2307 / 1485491$

LÉVI, C. 1991. Lithistid sponges from the Norkfolk Rise. Recent and Mesozoic genera, 72- 82. In Reitner, J. \& Keupp, H. (eds) Fossil and recent sponges. Springer Verlag, Berlin. DOI 10.1007/978-3-642-75656-6_7 
ŁuKowiak, M. 2015. Late Eocene siliceous sponge fauna of southern Australia: reconstruction based on loose spicules record. Zootaxa 3917(1), 001-065.

Maldonado, M., Carmona, M.C., Uriz, M.J. \& Cruzado, A. 1999. Decline in Mesozoic reef-building sponges explained by silicon limitation. Nature 401, 785-788.

DOI 10.1038/44560

MAREK, S. 1988. Palaeothickness, lithofacies and palaeotectonics of the epicontinental Lower Cretaceous in Poland. Kwartalnik Geologiczny 32, 157-174.

Miller, K.G., Kominz, M.A., Browning, J.V., Wright, J.D., Mountain, G.S., Katz, M.E., Sugarman, P.J., Cramer, B.S., Christie-Blick, N. \& PeKar, S.F. 2005. The Phanerozoic record of global sea-level change. Science 310, 1293-1298. DOI 10.1126/science. 1116412

Moret, L. 1926. Contribution à l'étude des spongiaires siliceux du Crétacé supérieur français. Mémoire de la Société géologique de France, nouvelle série 5, 1-314.

Moryc, W. 1997. The Lower Cretaceous in the pre-Miocene substratum of the southern part of the Carpathian Foredeep in Poland. Annales Societatis Geologorum Poloniae 67, 287-296.

NestLER, H. 1961. Spongien aus der weissen Schreibkreide (unter Maastricht) der Insel Rügen (Ostsee). Paläontologische Abhandlungen 1, 1-70.

Neumann, A.C., Kofoed, J.W. \& Keller, G.H. 1977. Lithoherms in the Straits of Florida. Geology 1, 4-10. DOI 10.1130/0091-7613(1977)5<4:LITSOF>2.0.CO;2

Neuwailer, F. \& Burdige, D.J. 2005. The modern calcifying sponge Spheciospongia vesparium (Lamarck, 1815), Great Bahama Bank: Implications for ancient sponge mud-mounds. Sedimentary Geology 175, 89-98.

DOI 10.1016/j.sedgeo.2004.12.021

OкоŃSKI, S., GóRnY, Z., BĄK, M. \& BĄK, K. 2014. Lithistid spicules in the sediments of the Turonian Variegated Shale in the Silesian Nappe, Polish Outer Carpathians. Geology, Geophysics \& Environment 40, 33-48.

DOI 10.7494/geol.2014.40.1.33

OlszewsKa-NejBert, D. \& ŚwiercZewsKa-GŁadysz, E. 2011. Campanian (Late Cretaceous) hexactinellid sponges from the white chalk of Mielnik (Eastern Poland). Acta Geologica Polonica 61(4), 38-417.

Olszewska-Nejbert, D. \& ŚwiercZewsKa-GŁadysz, E. 2013. Cenomanian (Late Cretaceous) siliceous sponges from Nezvys'ko and Rakovets' (Pokuttian Podillia, western Ukraine). Cretaceous Research 43, 116-144.

DOI 10.1016/j.cretres.2013.03.001

OszCZYPKO, N. 2004. The structural position and tectonosedimentary evolution of the Polish Outer Carpathians. Przeglad Geologiczny 52, 780-791.

Peryt, D. 1983. Mid-Cretaceous microbiostratigraphy and foraminifers of the NE margins of the Świętokrzyskie (Holy Cross) Mts., Poland. Acta Paleontologica Polonica 28, 417-466.

Pisera, A. 1997. Upper Jurassic siliceous sponges from the Swabian Alb: taxonomy and paleoecology. Palaeontologia Polonica 57, 1-214.

Pisera, A. 1999. Post-Palaeozoic history of the siliceous sponges with rigid skeleton. Memoires of the Queensland Museum 44, 463-472.
Pisera, A. 2006. Palaeontology of sponges - a review. Canadian Journal of Zoology 84, 242-261. DOI 10.1139/z05-169

Pisera, A., Cachão, M. \& Silva, C.M. 2006. Siliceous sponge spicules from the Miocene Mem Moniz marls (Portugal) and their environmental significance. Rivista Italiana di Paleontologia e Stratigrafia 112(2), 287-299.

Pisera, A. \& Lévi, C. 2002a. Family Corallistidae Sollas, 312-320. In HoOper, J.N.A. \& VAN Soest, R.W.M. (eds) Systema Porifera. Kluwer Academics/Plenum Press, New York.

PiserA, A. \& LÉvi, C. 2002b. Family Phymaraphiniidae Schrammen, 380-383. In HoOper, J.N.A. \& VAN Soest, R.W.M. (eds) Systema Porifera. Kluwer Academics/Plenum Press, New York.

Pisera, A. \& LÉVI, C. 2002c. Family Phymatellidae Schrammen, 366-373. In Hooper, J.N.A. \& Van Soest, R.W.M. (eds) Systema Porifera. Kluwer Academics/Plenum Press, New York.

Pisera, A. \& LÉVI, C. 2002d. Family Theonelleidae Lendenfeld, 327-337. In Hooper, J.N.A. \& VAN Soest, R.W.M. (eds) Systema Porifera. Kluwer Academics/Plenum Press, New York.

Pisera, A., Satir, M., Gruszczyński, M., Hoffman, A. \& MatkowsKi, K. 1992. Variation in $\delta^{13} \mathrm{C}$ and $\delta^{18} \mathrm{O}$ in late Jurassic carbonates, Submediterranean Province, Europe. Annales Societarum Geologorum Poloniae 62, 141-147.

Pratt, B.R., Bourque, P.A. \& Gignac, H. 1986. Sponge-constructed stromatactis mud mounds, Silurian of Gaspe, Quebec; discussion and reply. Journal of Sedimentary Research 56, 459-463.

DOI 10.1306/212F894F-2B24-11D7-8648000102C1865D

REID, R.E.H. 1958. A monograph of the Upper Cretaceous Hexactinellida of Great Britain and Northern Ireland, part II, 1-26. Palaeontographical Society, London.

REID, R.E.H. 1962. Sponges and the Chalk Rock. Geological Magazine 99, 273-278. DOI 10.1017/S0016756800058313

REID, R.E.H. 2004. Mesozoic and Cenozoic choristid demosponges, 175-198. In Rigby, J.K., Finks, R.M. \& ReId, R.E.H. (eds) Treatise on Invertebrate Paleontology. Part E, Vol. 3. Porifera. Geological Society of America \& University of Kansas Press, Boulder \& Lawrence.

Reitner, J. 1987. Mikrofazielle, paläekologische und paläogeographische analyse ausgewählter vorkommen flachmariner Karbonate im Basko-Kantabrischen Strike Slip Fault-Becken-System (Nordspanien) an der Wende von der Unterkreide zur Oberkreide. Documenta naturae 40, 1-239.

ReitNeR, J. 1993. Modern cryptic microbialite-metazoan facies from Lizard Island (Great Barrier Reef, Australia) - formation and concepts. Facies 29, 3-40. DOI 10.1007/BF02536915

Reitner, J. \& KeupP, H. 1991. The fossil record of the haplosclerid excavating sponge Aka de Laubenfels, 102-120. In Reitner, J. \& Keupp, H. (eds) Fossil and Recent Sponges. Springer Verlag, Berlin.

Reitner, J., Neuweiler, F. \& Gautret, P. 1995. Modern and fossil automicrites: implications for mud-mound genesis. Facies 32, 4-17.

Rice, A.L., Thurston, M.H. \& New, A.L. 1990. Dense aggregations of a hexactinellid sponge, Pheronema carpenteri, in the 
Porcupine Seabight (northeast Atlantic Ocean) and possible causes. Progress in Oceanography 24, 179-206. DOI 10.1016/0079-6611(90)90029-2

Roemer, F.A. 1864. Die Spongitarien des norddeutschen Kreidegebirges. Palaeontographica 13, 1-63.

Rотнwell, R.G. 1989. Minerals and mineraloids in marine sediments: An optical identification guide. 279 pp. Elsevier Applied Science, London. DOI 10.1007/978-94-009-1133-8

Schrammen, A. 1910. Die Kieselspongien der oberen Kreide von Nordwestdeutschland. I. Teil. Tetraxonia, Monaxonia und Silicea incertae sedis. Palaeontographica 5, Supplement, $1-175$.

Schrammen, A. 1910-1912. Die Kieselspongien der oberen Kreide von Nordwestdeutschland. Palaeontographica 5, Supplement, 1-385.

Sujkowski, Z. 1933. Sur certains spongiolithes de la Tatra et des Karpates. Sprawozdania - Państwowy Instytut Geologiczny 7, $712-733$.

ŚwierCZewska-GŁadysz, E. 2006. Late Cretaceous siliceous sponges from the Middle Vistula River Valley (Central Poland) and their palaeoecological significance. Annales Societatis Geologorum Poloniae 76, 227-296.

ŚwIERCZEWSKA-GŁADYSZ, E. 2012. Hexactinellid sponge assemblages across the Campanian-Maastrichtian boundary in the Middle Vistula River section, central Poland. Acta Geologica Polonica 62(4), 561-580. DOI 10.2478/v10263-012-0030-y

Termier, G. \& Termier, H. 1980. Spongiaires du Crétacé Moyen. Cretaceous Research 2, 427-433. DOI 10.1016/0195-6671(81)90031-8

Trest'JAN, G.N. 1972. New glass sponges (Hyalospongiae) from the Upper Cretaceous of the Pridnestrovie. Paleontologicheskii zhurnal 6, 171-179. [in Russian]

UnRUG, R. 1959. On the sedimentation of the Lgota beds. Rocznik Polskiego Towarzystwa Geologicznego 29, 197-225.

UnRUG, R. 1977. Ancient deep-sea traction currents deposits in the Lgota beds (Albian) of the Carpathian Flysch. Rocznik Polskiego Towarzystwa Geologicznego 47, 355-370.

Ulbrich, H. 1974. Die Spongien der Ilsenburg-Entwicklung (Oberes Unter-Campan) der Subherzynen Kreidemulde. Freiberger Forschungshefte C 291, 1-121.

UrIZ, M.J. 2002. Family Geodiidae Gray, 1867, 134-140. In Hooper, J.N.A. \& VAN Soest, R.W.M. (eds) Systema Porifera. Kluwer Academics/Plenum Press, New York.

VAcelet, J. 1975. Étude en microscopie électronique de l'association entre bactéries et spongiaires du genre Verongia (Dictyoceratida). Journal of Microscopy 23, 271-288.

Van Weering, T.C.E., De HaAs, H., De Stigter, H.C., LykKe-Andersen, H. \& Kouvaev, I. 2003. Structure and development of Giant carbonate mounds at the SW and SE Rockall Trough margin. Marine Geology 198, 67-83.

DOI 10.1016/S0025-3227(03)00095-1

Voigt, S., Aurag, A., Leis, F. \& Kaplan, U. 2007. Late Cenomanian to Middle Turonian high-resolution carbon isotope stratigraphy: New data from the Münsterland Cretaceous Basin, Germany. Earth and Planetary Science Letters 253, 196-210. DOI 10.1016/j.eps1.2006.10.026

WARNKE, K. 1995. Calcification processes of siliceous sponges in Viséan limestones (counties Sligo and Leitrim, Northwestern Ireland). Facies 33, 215-228. DOI 10.1007/BF02537453

Whitney, F., Conway, K., Thomson, R., Barrieb, V., Krautter, M. \& Mungov, G. 2005. Oceanographic habitat of sponge reefs on the Western Canadian continental shelf. Continental Shelf Research 25, 211-226. DOI 10.1016/j.csr.2004.09.003

WiedenMayer, F. 1980. Siliceous sponges; Development through time, 55-85. In Hartman, W.D., WendT, J.W. \& WiedenMAYer, F. (eds) Living and fossil sponges. Notes for a short course, Sedimenta 8.

Wiedenmayer, F. 1994. Contribution of the knowledge of post-Paleozoic neritic and archibenthal sponges (Porifera). Schweizerische Paläontologische Mitteilungen 116, 1-147. 